\title{
ON THE WOOD ANATOMY OF THE TRIBE "OLMEDIEAE" (MORACEAE) AND THE POSITION OF THE GENUS OLMEDIA R. \& P.
}

\author{
ALBERTA M. W. MENNEGA and MARIJKE LANZING-VINKENBORG \\ Instituut voor Systematische Plantkunde, Utrecht
}

\section{SUMMARY}

The structure of the wood of the genera Castilla, Helicostylis, Maquira, Naucleopsis, Olmedia, Perebea and Pseudolmedia, considered to belong in the Olmedieae (cf. BERG 1972) is described. The diversity in anatomical structure between the genera is small, and it is hard to distinguish Maquira, Perebea and Pseudolmedia from each other. Castilla can be recognized by its thinwalled and wide-lumined fibres, Helicostylis by its parenchyma distribution, Naucleopsis (usually) by its more numerous vessels with a smaller diameter. A more marked difference is shown by the monotypic genus Olmedia with apotracheal banded parenchyma instead of the paratracheal aliform to confluent-banded parenchyma of the other genera. Septate fibres, which are characteristic for the other genera - some species of Helicostylis excepted - are nearly completely absent in Olmedia. This structural difference is considered as an argument in favour of the exclusion of Olmedia from the tribe Olmedieae (BERG 1977).

\section{INTRODUCTION}

The structure of the secondary wood of the Moraceae shows in comparison to that of many other families a rather uniform pattern. This is particularly true for most genera of the tribe Olmedieae. Differences are mainly found in size and number of vessels, absence or presence of septate fibres, and in the distribution and quantity of axial parenchyma. Besides the description of the Moraceae in Metcalfe \& ChalK's Anatomy of the Dicotyledons (1950), we have TIPPO's (1938) account of the family and a treatment of the American genera by RECORD \& Hess (1940). The latter authors pointed out how unreliable their material was, even originating from type trees, because the botanists who proposed the new species were sometimes uncertain as to the genera to which these species should be assigned.

In recent time several taxonomic revisions were published among which BERG's (1972) "Revision of the Neotropical Olmedieae and Brosimeae." While Berg studied the taxonomy of the Olmedieae, the second author investigated the wood structure of our material of the genera at that time considered to belong to the Olmedieae. It appeared from her study (unpublished doctorate thesis) that differences in wood structure between the species, although small, do enable a certain arrangement into groups. She drew her conclusions from anatomy independantly from Berg's taxonomical results. A subsequent comparison of their respective conclusions showed that the 
arrangement of the wood samples agreed remarkably well with the taxonomic arrangement.

It seemed desirable to wait with publication of the results of the anatomical investigation until additional material in genera not or poorly represented up till then would be available. As appears from table 1 all seven genera which, according to BERG (1972), constitute the tribe Olmedieae are now represented in a most satisfactory way. Among others the genus $O$ lmedia is now represented. In a recent paper BERG (1976) points out that the genus Olmedia must be excluded from the tribe Olmedieae for various reasons. This necessitated a redefinition of the tribe and a new name for it: Castilleae C. C. Berg. For practical reasons the present paper still refers to the Olmedieae in the former wide sense.

\section{MATERIAL AND METHODS}

The material is listed in table 1 . In the table the revised names as well as the scientific names which accompanied the wood specimens received from other institutes are listed. In those cases where the material was very abundant a selection was made of the samples to be sectioned, the other ones being inspected by a $\times 10$ hand lens. All wood specimens are backed by herbarium vouchers which were identified by Berg.

In the usual way sections and macerations were prepared for studying the microscopical characters. For some of the specimens softening in hydrofluoric acid previous to cutting was necessary. Macerations were made by placing wood chips overnight in a mixture of equal parts of acetic acid and hydrogen peroxide at a temperature of $60^{\circ} \mathrm{C}$.

In the generic descriptions the averages for the length of vessel members and fibres are calculated from the average values for the species, the lowest and highest averages being placed between brackets. The ranges comprise the lowest and highest values encountered within the species.

\section{GENERAL ANATOMICAL CHARACTERS OF THE WOOD}

Characteristic for all genera are the scattered vessels with simple perforations and moderate to rather large alternate intervascular pits ranging from 5.5-10 $\mu \mathrm{m}$; vessel members with short tips or without tips, and a length of about $400-$ $500 \mu \mathrm{m}$. The fibre tissue consists of libriform with small simple pits on the radial walls. Mostly fibres are septate with 1-3 septae per fibre, but in some genera, like Helicostylis, only part of the fibres are septate and in Olmedia septate fibres are extremely scarce. In a number of the fibres gelatinous walls are nearly always present. The majority shows the long spindle form and ranges from 1000-1700 $\mu \mathrm{m}$ long, but shorter fibres with a wider body and more abruptly ending in bayonet-like tips are also present. In Castilla the fibres are wider and thinner-walled than in the other genera; in Naucleopsis they tend to be slightly shorter than in the other genera. The ratio of fibre to vessel member 


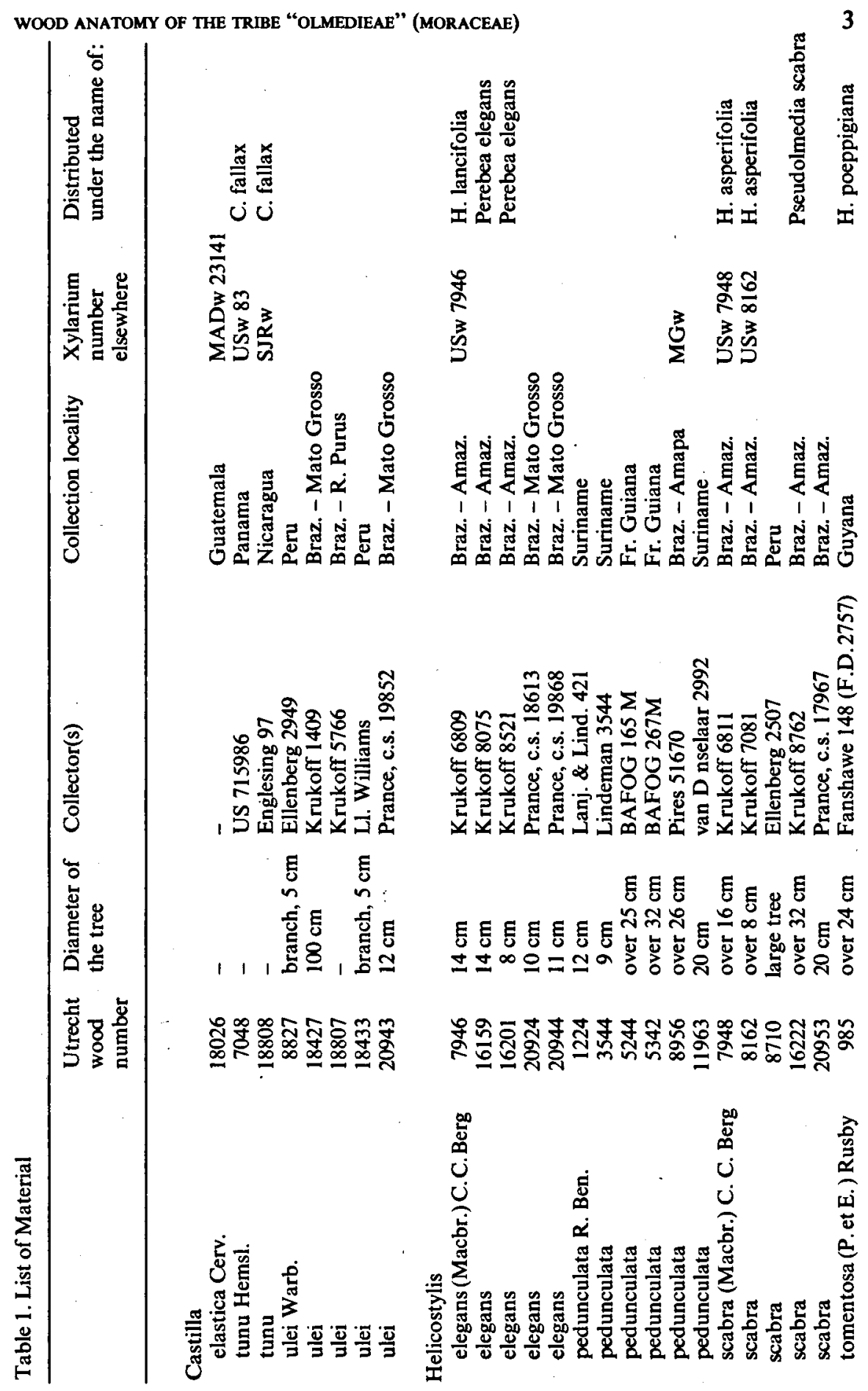




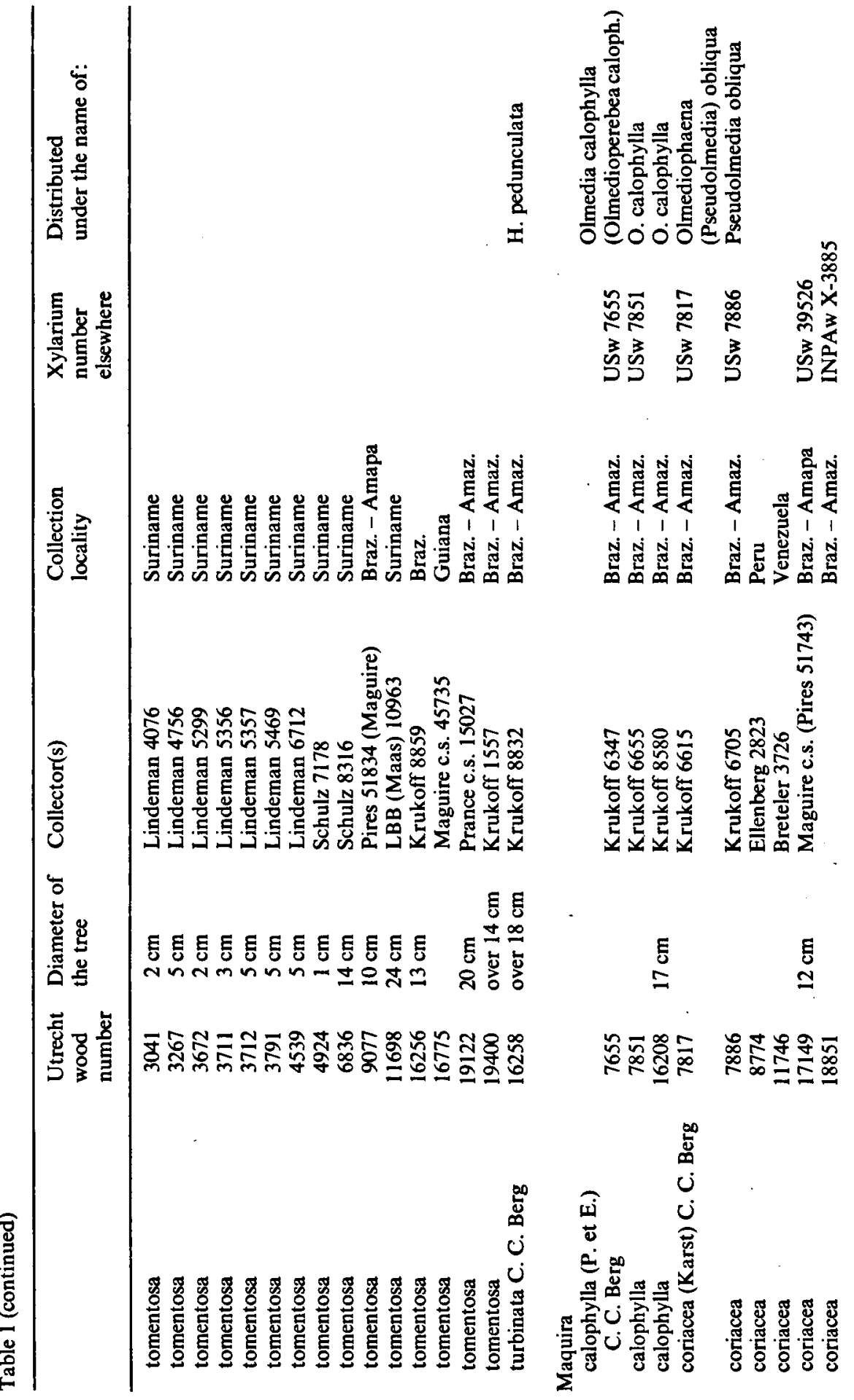


WOOD ANATOMY OF THE TRIBE “OLMEDIEAE” (MORACEAE)

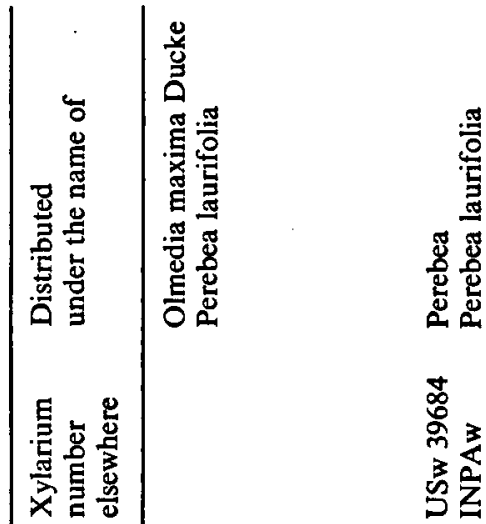

荧

:

号

号

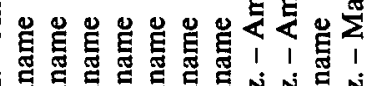

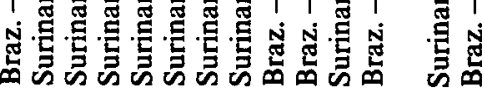

齐

댕

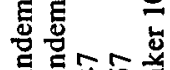

包

กั

ธุด

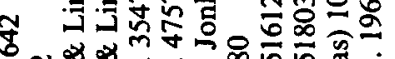

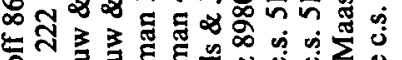

导m

㿣

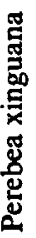

莺

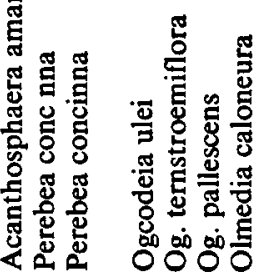

$\underset{\infty}{\infty} \underset{\infty}{\infty}$

芯苛

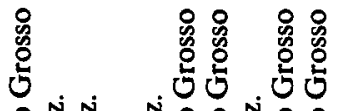

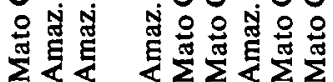

111111

กี่

祃

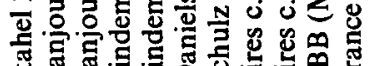

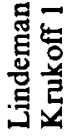

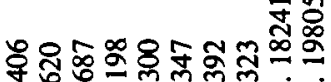

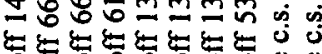

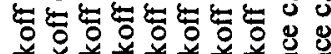

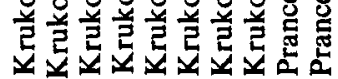

E

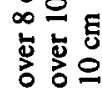

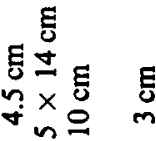

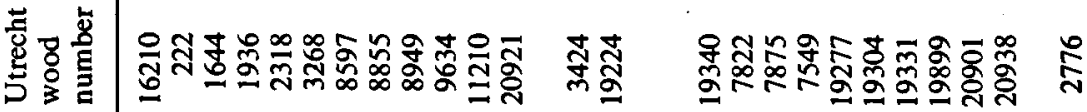

हี

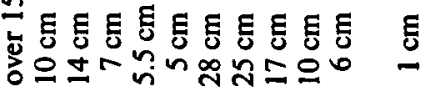

点

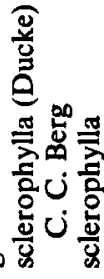




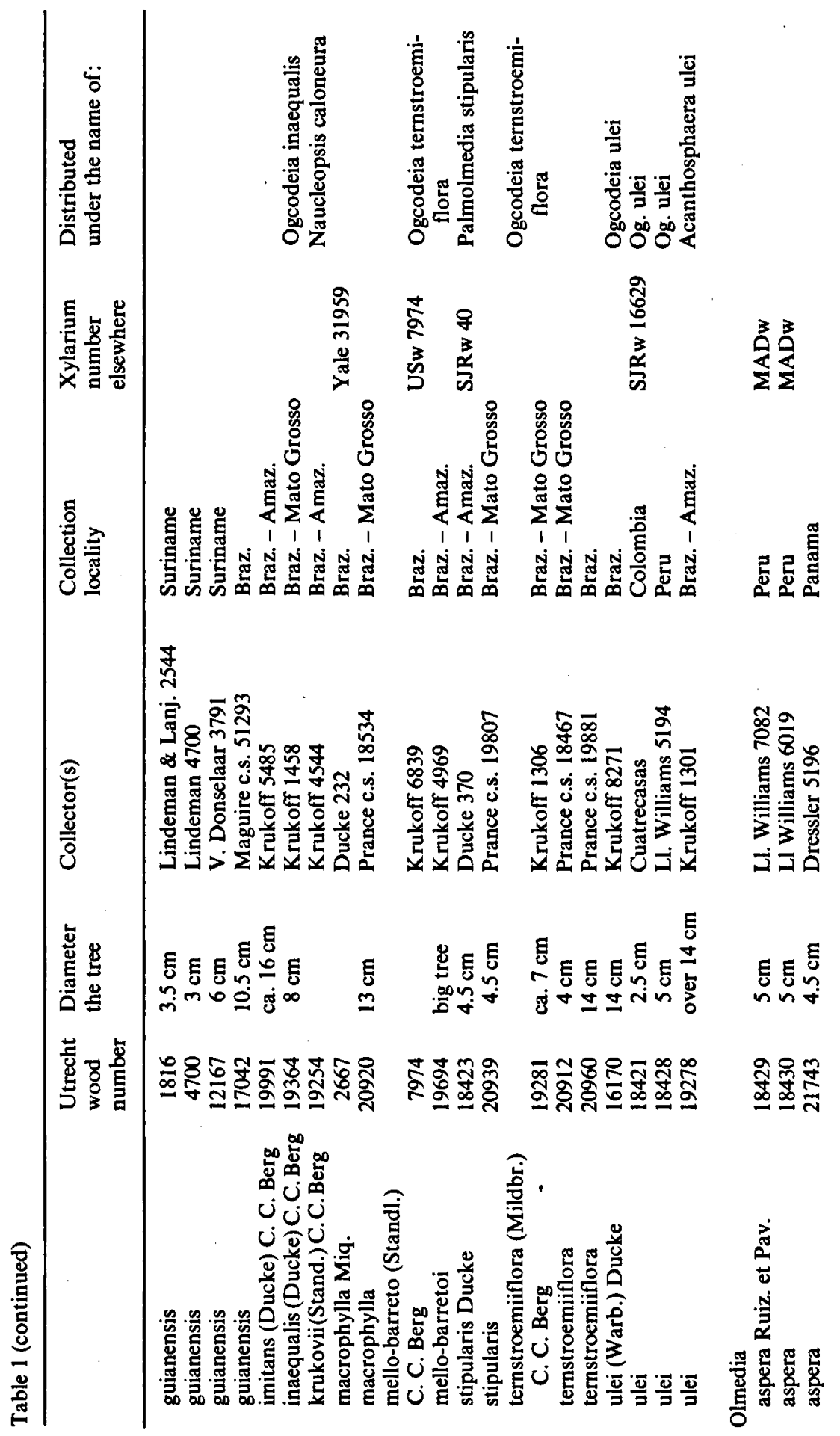




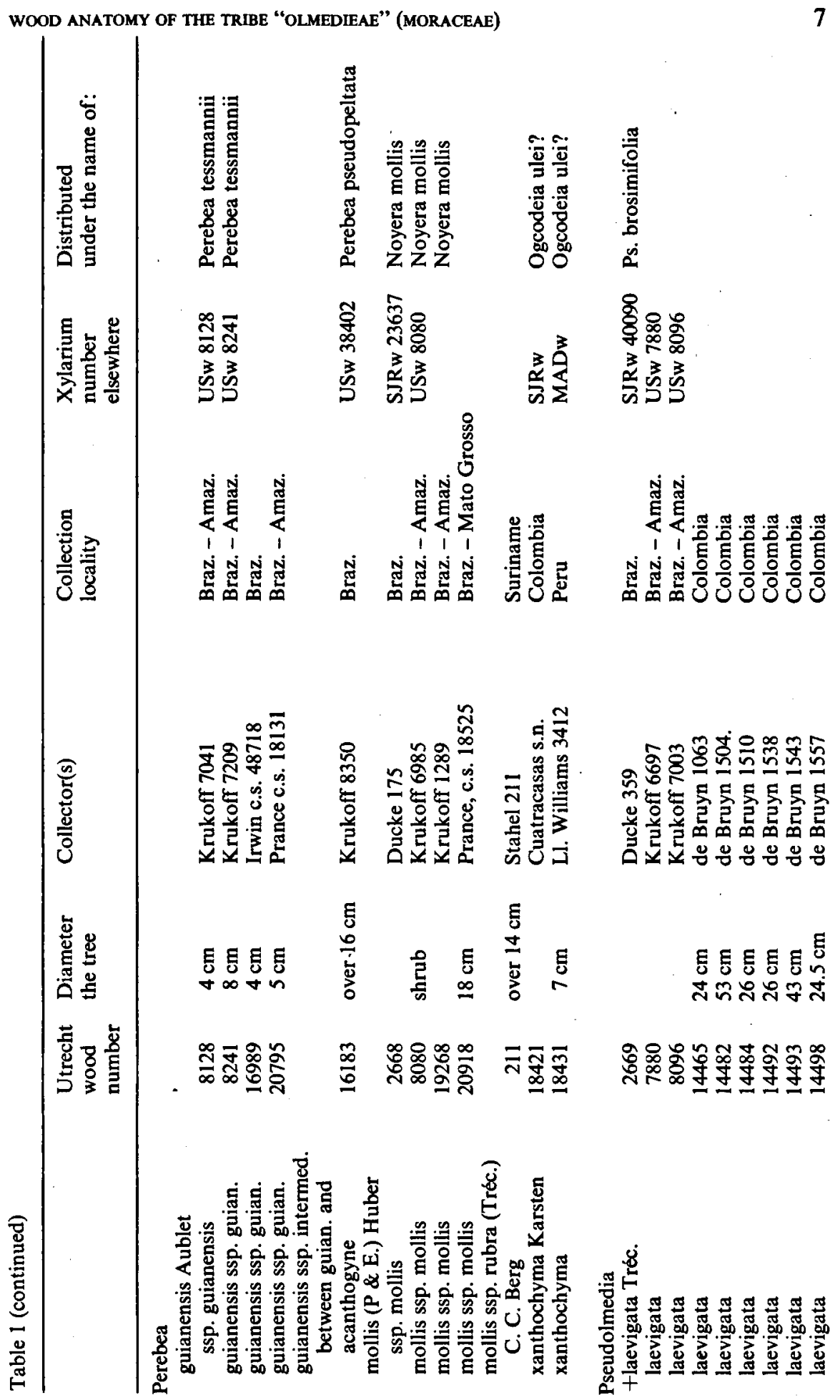




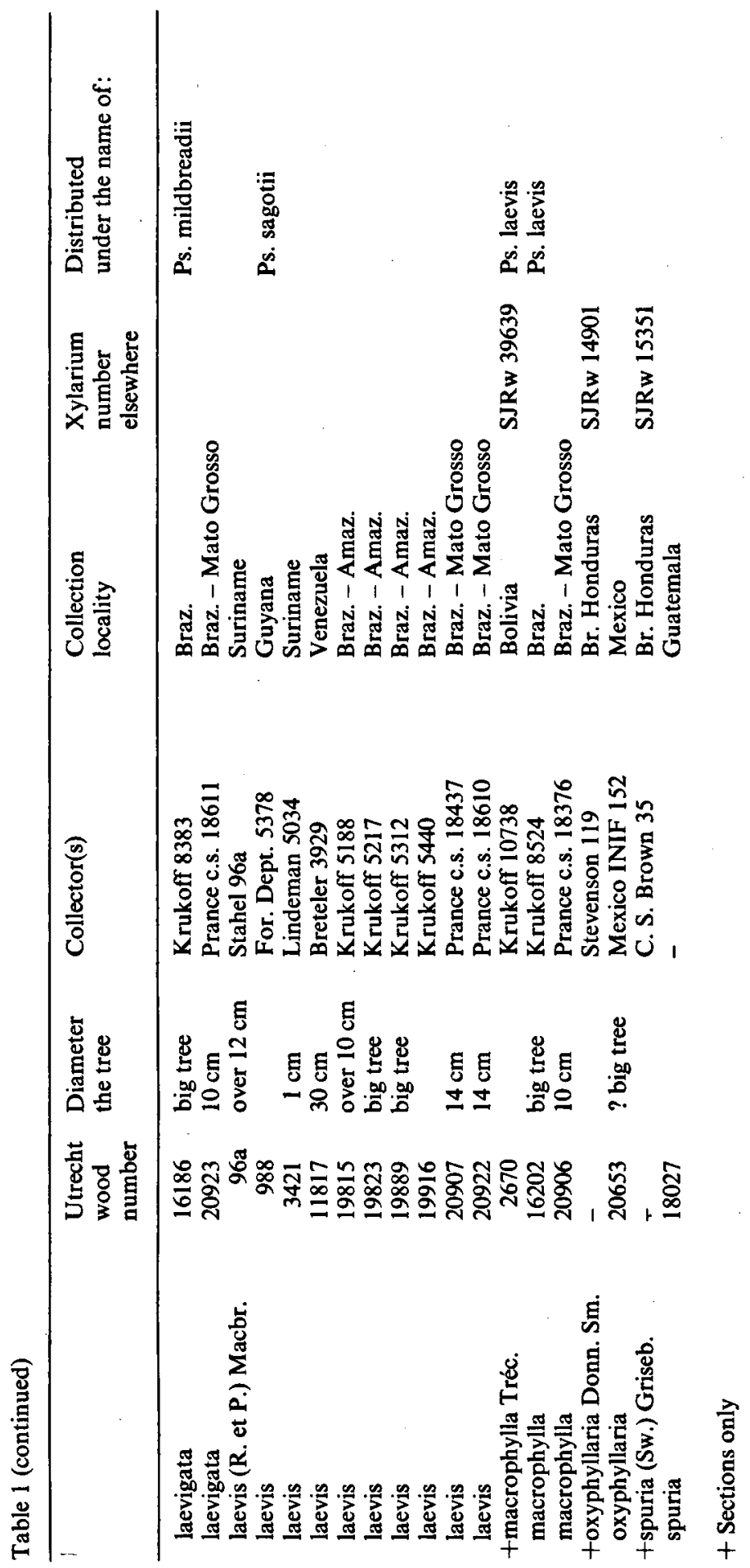


length is moderately high as it ranges between $2-3$. In the ray tissue the scarcity of uniseriate rays is characteristic; the multiseriates range from 2-8 cells wide, they mostly consist of numerous rows of low procumbent cells bordered by short uniseriate wings, the highest rays up to $2.6 \mathrm{~mm}$ high ( 165 cells), are often diagonally dissected by one or two fibres. Rays are seldom in contact with the vessels, consequently ray/vessel pitting is rare and restricted to occasional halfbordered round pits in the procumbent cells and larger oval pits in the square and upright cells. Narrow latex tubes occur in the rays of all genera except Olmedia. Crystals may be present but usually are not abundant; brown or yellowish contents are generally present. Parenchyma, except in Olmedia, is always paratracheal in mostly incomplete, vasicentric, aliform rings, the lateral wings locally confluent or even forming confluent banded parenchyma. A narrow terminal band is occasionally present. Strands of 2-4 (8) cells; in the 2-celled strands the individual cells sometimes with long pointed ends, resembling short fibres. Crystals rather scarce, but abundant in long rows of divided cells in Pseudolmedia oxyphyllaria. Brown contents generally present. Pits to vessels large, oval or irregular, mainly in horizontal arrangement. In Olmedia the parenchyma distribution is different, the parenchyma occurring in wide, regular, apotracheal bands.

\section{KEY TO THE WOOD OF THE OLMEDIEAE}

It was not without hesitation that a key to the genera was prepared. In this rather homogeneous group of genera it is extremely difficult to find distinguishing characters which are sufficiently clearly defined to allow someone not familiar with the tribe to identify his material. This difficulty is enhanced by the fact that in large genera represented by much material usually an odd sample is likely to be present that does not correspond to the general picture of the genus. Aberrant features are usually found in the parenchyma distribution and the average vessel number. From a detailed investigation of the material of Helicostylis tomentosa (table 2) it appeared that stems and branches with a diameter of less than $5 \mathrm{~cm}$ differ a great deal in those features from more mature stems. Therefore samples from such small-sized stems or branches cannot be identified with much certainty.

All this applies to the genera Helicostylis, Maquira, Naucleopsis, Perebea and Pseudolmedia. The other genera, Castilla and Olmedia, are easily distinguished, mainly on the basis of general texture, and parenchyma distribution and absence of latex tubes respectively. Maquira and Perebea are so much alike that they can hardly be distinguished by their wood. Though the absence of dark brown contents in the ray and parenchyma cells is often characteristic for Maquira, as it comes true for the majority of specimens, it is not sufficiently distinctive for all samples. Neither is the usually abundant presence of dark brown contents in the parenchymatic cells of Pseudolmedia a constant and reliable feature that may be used for diagnostic purposes. Taking into account what is pointed out above, the following tentative key is proposed: 
1. Parenchyma in straight, moderately broad, regularly spaced, apotracheal bands; fibres not septate or exceptionally so: latex tubes absent . Olmedia Parenchyma vasicentric, short to long aliform, or locally or generally aliform/confluent to confluent banded . . . . . . . . . . 2

2. Wood cream-coloured; weight light, c. 0.40 ; texture course; fibres thinwalled with a large lumen and a diameter of $20-35 \mu \mathrm{m} \ldots$. . Castilla Wood yellowish brown to middle brown, the heartwood sometimes darker brown or with dark streaks; moderately heavy to heavy; fibres thick-walled to moderately thick-walled with a diameter of $15-25 \mu \mathrm{m} \ldots . . . .3$

3. Vessels moderately numerous to numerous, $20-35$ per square $\mathrm{mm}$ on the average, diameter $70-100(120) \mu \mathrm{m}$; fibres all septate with $2-3$ septae per fibre . . . . . . . . . . . Naucleopsis p.p. Vessels less numerous, 5-15 per square mm on the average, diameter 90 $150(200) \mu \mathrm{m}$ : fibres usually septate but septae often absent in most fibres in Helicostylis . . . . . . . . . . . . . . . . 4

4. Rays 4-6 per mm; vessels $100-200 \mu \mathrm{m}$ wide, usually over $140 \mu \mathrm{m}$ : intervascular pits generally 8-10 $\mu \mathrm{m}$; parenchyma in complete, short-aliform rings . . . . . . . . . . . . . . . Helicostylis Rays 6-9 per mm; vessels less wide, intervascular pits 5-8 $\mu \mathrm{m}$. . . . . 5

5. Parenchyma generally aliform-confluent, forming wavy tangential bands; rays often diagonally dissected by a few fibres (tg. sections) . Pseudolmedia Parenchyma vasicentric, aliform, only locally confluent or forming interrupted bands (the bands more pronounced in Perebea mollis and Perebea xanthochyma) . . . . Maquira, Perebea, Naucleopsis amara, N. ulei

\section{DESCRIPTION OF THE GENERA}

1. Castilla Sessé

plate I, fig. 1,2

A genus of three species, each represented by one or more wood samples. (table 1).

General characters

According to Williams (1936), Record \& Mell (1924), Record \& Hess (1940, 1944) without clear demarcation between sapwood and heartwood; the sapwood light yellowish brown; texture coarse; straight-grained; rather light, vol. weight c. 0.40 .

Microscopical characters

Vessels: Few to moderately few, 3-6 (2-9) per sq. mm, sometimes nearly all solitary, but generally for about $50 \%$ in radial multiples of 2-4 or in longer dumb-bell shaped rows or in irregular clusters; fairly regularly distributed; outline oval or rounded, tang. diameter $160-200(100-300) \mu \mathrm{m}$; perforations simple; intervascular pits $8-10 \mu \mathrm{m}$, the border angular; thin or hard tyloses occasionally present; vessel members on the average $420(200-700) \mu \mathrm{m}$ long. Fibres: All or partly septate, in C. elastica and C. tunu with one or two septae, in the material of C. ulei the occurrence of septae variable; diam. 20-28(35) $\mu \mathrm{m}$; 
walls very thin, $2-3 \mu \mathrm{m}$; length on average $1270(600-1900) \mu \mathrm{m}$; simple pits on radial walls only. Fibre/vessel member length ratio 3 (2.6-3.7).

Rays: 1 and 2-6 cells wide. The uniseriates comprising c. $25 \%$. but scarce in two samples of $C$. ulei; up to 30 cells $(650 \mu \mathrm{m})$ high, consisting of square and upright cells. The multiseriates generally $2-6$ cells wide, but 3 cells wide in one sample of $C$. ulei, the narrow multiseriates usually with long uniseriate wings, in the samples with the widest rays the wings $2-3$ cells high, and the individual upright cells less high than in the samples with long uniseriate wings; width from 20-90 $\mu \mathrm{m}$; height up to $1 \mathrm{~mm}$ or more, if vertically fused, which occurs more frequently in the narrow type of rays, up to $1700 \mu \mathrm{m}$; pits to vessels scarce, round and half-bordered to oval, mainly in the square and upright cells. Latex tubes present in all species, though rather scarce in some samples of $C$. ulei. In one sample of $C$. tunu (Uw 7046) sclerotic ray cells present. Number 4-8 per mm.

Parenchyma: Paratracheal, mostly restricted to narrow vasicentric or shortaliform rings, occasionally confluent into a narrow band, however up to 8 cells wide bands present in $C$. elastica, and in one sample of $C$. ulei nearly all parenschyma banded, the bands $12-20$ cells wide $(240 \mu \mathrm{m})$, concentric, regular and completely enveloping the vessels. Strands of $2-4(8)$ cells. Pits to vessel large, oval, and elongated.

Diagnostic characters

All samples share the extremely thin-walled, wide fibres, and the resulting rather light weight of the wood.

\section{Remarks}

The variation in distribution of the parenchyma and in structure of the rays shown by the present material, is also apparent from the description given by RECORD \& Hess (1940). Williams (1936) described the parenchyma of the sample collected by him near Loreto as paratracheal and sometimes aliform.

\section{HELICOSTYLIS Trécul plate 1 , fig. 3, 4; plate $1 I I$, fig. 1}

In BERG's (1972) revision Helicostylis comprises seven species. Wood specimens from five of those were available. The type species of the genus $H$. tomentosa (P. et E.) Rusby is by far the most widespread and is also the best represented in our wood collection. Several of the wood specimens studied were originally assigned to other genera like Pseudolmedia and Perebea as appears from table 1 .

\section{General characters}

Sapwood a golden yellowish brown, c. $7-10 \mathrm{~cm}$ wide, the heartwood light brown in $H$. pedunculata to very dark brown in $H$. elegans and $H$. scabra, medium brown in the other species; sometimes with dark brown streaks on the tangential surfaces, in the cross section showing as irregular light and dark concentric zones; the demarcation between sapwood and heartwood generally irregular. Texture moderately fine; straight- or roey-grained; moderately hard and moderately heavy to heavy, vol. weight $0.50-0.86$. 


\section{Microscopical characters}

Vessels: Mostly moderately few, averages ranging from 5-12.5 (2-16) per sq. $\mathrm{mm}$, the highest average of 12.5 occurring in the sample of $H$. turbinata (Uw 16528 ); mostly solitary, for $10-30 \%$ in radial multiples of $2-3(5)$, scattered, but with a tendency towards a diagonal arrangement. Outline round, diameter 120-160 (200) $\mu \mathrm{m}$; perforations simple; intervascular pits 8-10 (12) $\mu \mathrm{m}$, but in one sample of $H$. scabra (Uw 16222) $4 \mu \mathrm{m}$, the borders oval or angular, the slits enclosed or extended and confluent. Thin tyloses often present. Vessel members on average $470(430-515) \mu \mathrm{m}$ long, ranging from $300-630 \mu \mathrm{m}$.

Fibres: Libriform, partly septate, the number of septate fibres variable for the same species, in some samples of $H$. tomentosa and $H$. scabra nearly all fibres non-septate, diam. $16-20 \mu \mathrm{m}$, in $H$. pedunculata $20-30 \mu \mathrm{m}$; walls occasionally gelatinous; pits restricted to the radial walls, small; the average length 1230 (1140-1380) $\mu \mathrm{m}$, the range $900-1700 \mu \mathrm{m}$. Fibre/vessel member length ratio on average $2.6(2.3-3.0)$.

Rays: 1 - and 2-5 cells wide. The uniseriates scarce, very low, mostly 3-5 (1-10) cells high, consisting of square and upright cells. The multiseriates mostly 3-4 cells (40-50 $\mu \mathrm{m}$ ) wide, but in $H$. pedunculata and in $H$. turbinata and in one sample of $H$. scabra 50-80 $\mu \mathrm{m}$ wide; in the other sample of $H$. scabra and in $H$. elegans $2-4$ cells $(20-40) \mu \mathrm{m}$ wide; the uniseriate wings generally very low, however, sometimes up to 6 or 8 cells high; vertically fused rays present but not abundant, normally height $300-800 \mu \mathrm{m}$, but also rays of $1300-1500 \mu \mathrm{m}$ ( $70-90$ cells) high present; sheath cells locally. Pits to vessels scarce, large, irregular, or half-bordered and round, mainly restricted to the square and upright cells. Latex tubes present. Crystals occasionally present; brown contents frequent in two samples of $H$. scabra, absent or very scarce in the other species. Number on average 5 (4-7) per mm.

Parenchyma: Paratracheal, usually as a moderately broad ring completely surrounding the pores, and broadened laterally; in $H$. turbinata often confluent and locally forming long uninterrupted bands $7-8$ cells wide, in the other species also locally confluent, but the bands narrower and less conspicuous; sometimes a straight narrow band suggesting marginal parenchyma present. Strands of 2-8 cells, mostly 4 cells. Brown contents often present, crystals and sclerotic cells occasionally noticed. Pits to vessels large, irregular to oval, often horizontally arranged.

Diagnostic characters

The medium-sized vessels, the short-aliform vasicentric parenchyma, and the moderately few rays are characteristic for Helicostylis.

\section{Remarks}

Helicostylis is one of the genera of the Olmedieae which can be recognized moderately well by its anatomical features. At least no great difficulties were encountered in assigning a large number of Moraceous wood samples backed by sterile herbarium twigs to this genus, which identifications were later on confirmed by Berg.

RECORD \& MELL (1924) mentioned in their description of the genus the different 
distribution of the parenchyma in material of $H$. latifolia Pitt. as compared to $H$. poeppigiana. To them the long and narrow aliform parenchyma of $H$. latifolia is suggestive of the genus Brosimum. In Berg's revision $H$. latifolia Pitt. was indeed transferred to Brosimum alicastrum.

\section{MAQUIRA Aublet}

plate III, fig. 3; plate IV, fig. I

Aublet's genus Maquira reestablished by BERG (1972) comprises a.o. M. guianensis Aubl. formerly known as Perebea laurifolia Tréc., a relatively common tree in the Guyanas. Furthermore Ducke's genera Olmedioperebea and Olmediophaena, as well as all species of Olmedia with the exception of $O$. aspera $\mathbf{R}$. et $\mathbf{P}$., were assigned by Berg to Maquira. The genus consists of five species, all of which are represented by wood samples (table 1 ).

General characters

Without clear demarcation of sapwood and heartwood; straw-coloured or light brown, in one sample of $M$. guianensis with irregular dark patches in the central part of the stem; irregular light and dark concentric zones may be conspicuous on the polished cross surface of a stem. Texture rather fine: straight- or roey-grained; moderately hard; heavy, vol. weight 0.70-0.90.

Microscopical characters

Vessels: Number variable from 6-26 per sq. $\mathrm{mm}$, most numerous in $M$. coriacea but the same value of 11-23 per sg. mm also occurs in some samples of $M$. guianensis; mostly solitary, for $20-40 \%$ in radial multiples of $2-3$, or in clusters; scattered or rather irregularly distributed without a definite pattern; outline oval to nearly round, tang. diameter $100-160 \mu \mathrm{m}$; perforations simple; intervascular pits on the average $8(6-11) \mu \mathrm{m}$, border angular, slits enclosed: thin tyloses sometimes present; length of vessel members on the average $500(390$ 580) $\mu \mathrm{m}$, range $260-850 \mu \mathrm{m}$.

Fibres: Libriform. The fibres septate with one or two septae; diameter 16-26 $\mu \mathrm{m}$, lumen as wide as or narrower than the breadth of the walls, but in $M$. sclerophylla the lumen wider; occasionally with gelatinous walls; length on the average $1225(1100-1400) \mu \mathrm{m}$, ranging from $800-1700 \mu \mathrm{m}$. Fibre/vessel member length ratio $2.6(2.1-3)$.

Rays: 1-seriate and (2) 3-5(8)-seriate. The uniseriates very few, mostly about 7 cells high, sometimes $15-17$, consisting of square and upright cells. The multiseriates of variable width even within a species, but generally 3-5 cells (40-70 $\mu \mathrm{m})$ wide, widest in $M$. coriacea and $M$. sclerophylla (4-8 cells): the uniseriate wings usually $1-3$ cells high, occasionally much higher; height variable, mostly $20-60$ cells $(300-800 \mu \mathrm{m})$, but often some rays 100 cells $(1200-1400 \mu \mathrm{m})$ high present, and those high and wide rays dissected diagonally by one or two fibres; vertically fused rays present but scarce; sheath cells rare. Light brown to brown contents often present, crystals scarce. Pits to vessels scarce, rounded, half bordered, mainly in the square and upright cells. Latex tubes present. Number on the average 6-8 per mm.

Parenchyma: Paratracheal, generally in wide to rather narrow vasicentric, 
short-aliform rings, occasionally confluent into narrow bands, sometimes with a tendency to diagonal alignment of the vessels; however, in some specimens of M. guianensis wings and bands much better developed. Pits to vessels large and irregular. Crystals rare. Strands of 2-4 (8) cells.

Diagnostic characters

The lozenge-shaped parenchyma, occasionally confluent tangentially or diagonally over a short distance is the only constant feature to distinguish species of Maquira from Pseudolmedia, which it closely resembles in most characters. Admittedly distinction between individual specimens may prove impossible due to the great variability in the samples of a species, viz. $M$. guianensis. It is even more hazardous to distinguish Maquira from Perebea, while characters of the species here are often completely overlapping.

Remarks

As the reestablished genus Maquira includes so many species formerly assigned to several other genera, no description related to the genus itself nor to the majority of its species could be found in the literature. RECORD \& Hess (1940) referred to the aberrant structure of Perebea calophylla (Yw $23650=$ Ducke 188) now identified as $M$. calophylla, which did not fit either in Perebea nor in Olmedia, where it also had been placed. Under the paragraphs treating Olmedia and Olmedioperebea we also find references to species now placed in Maquira but since their descriptions are very brief and general a comparison with our data is hardly possible. In any case it is noticable that they drew attention to the fact that the abundant parenchyma of $O$. aspera is strongly different from that of the other species they treated under Olmedia.

\section{NAUCLEOPSIS Miquel}

plate III, fig. 2

According to BERG's (1972) conception of the genus, Naucleopsis comprises the species formerly assigned to Acanthosphaera, Ogcodeia, Palmolmedia, and two species earlier placed in Perebea: $P$. concinna and P. macrophylla. In the present circumscription there are 18 species in Naucleopsis, twelve of which are represented by wood samples.

General characters

Wood uniformly straw-coloured to yellow-brown, heartwood not seen but according to L. Williams (1936) dark brown in Ogcodeia tamamuri (syn. of $N$. glabra). RECORD \& HESs (1940) stated that the heartwood is pale brown and not clearly differentiated from the sapwood. Texture moderately fine, straightgrained. Moderately hard and moderately heavy, vol weight c. 0.75 .

Microscopical characters

Vessels: Fairly numerous to numerous, on the average 20-35 (16-50) per sq. $\mathrm{mm}$. but less numerous in $N$. amara (Uw 19340) and in $N$. ulei (Uw 18620) with $13(10-17)$ per sq. $\mathrm{mm}$; about $10-20(40) \%$ in radial rows of $2-4$, occasionally in longer rows and then the vessels often of diminishing diameter, or in irregular groups. Outline round to angular, diameter generally 70-100 $\mu \mathrm{m}$, in $N$. amara up to $140 \mu \mathrm{m}$; intervascular pits $5.5-7.5 \mu \mathrm{m}$, in some cases 
$9 \mu \mathrm{m}$ and in $N$. amara and $N$. ulei normally $8-10 \mu \mathrm{m}$. Thin tyloses seldom present. Vessel members on the average $450(400-500) \mu \mathrm{m}$ long, range 300 $670 \mu \mathrm{m}$.

Fibres: Libriform, nearly all fibres septate, with 2-3 septate per fibre. Diameter (12) $15-20 \mu \mathrm{m}$, relatively thin-walled, walls 3-4 $\mu \mathrm{m}$, but thicker (4-6 $\mu \mathrm{m}$ ) in $N$. glabra; gelatinous walls frequent; pits simple, exclusively on the radial walls; length variable within a sample, on the average $950(800-1060) \mu \mathrm{m}$, range $430-1400 \mu \mathrm{m}$. Fibre/vessel member length ratio on the average 2.1 (1.6-2.4).

Rays: 1- and 3-4 (6) cells wide. The uniseriates usually scarce, very low, 3-7 (14) cells high, with square and upright cells. The multiseriates in general 3-4 cells wide, the uniseriate wings with square and upright cells mostly not over two cells high, but occasionally much higher in one sample of $N$. glabra, in $N$. imitans, $N$. stipularis and $N$. ulei; width $25-50 \mu \mathrm{m}$; usually $20-60$ cells (700-1500 $\mu \mathrm{m}$ ) high, but some up to 100 cells $(2 \mathrm{~mm})$ or, when vertically fused, even $3 \mathrm{~mm}$ high. Pits to vessels scarce, rounded. Cell dimensions of the procumbent cells as seen on a radial section often very irregular. Latex tubes usually present but not abundant. Crystals generally present as well as brown cell contents. Average number 6-8 per $\mathrm{mm}$.

Parenchyma: Paratracheal, vasicentric with narrow and short aliform extensions, occasionally locally confluent over a short distance, the vasicentric ring often incomplete and absent on the adaxial side of the vessels. In one specimen of $N$. guianensis and in $N$. macrophylla marginal parenchyma is present as a one cell wide band; in $N$. inaequalis, $N$. ternstroemiiflora and $N$. ulei growth rings are sometimes indicated by a 3-5 cells wide marginal band. Strands of $4(2-8)$ cells. Pits to vessels large and irregular, or oval and in horizontal rows. Brown cell contents usually present; crystals rare.

Diagnostic characters

Fairly numerous and rather narrow to moderately wide vessels, except in one sample of $N$. amara and of $N$. ulei with less numerous vessels of a larger size. Intervascular pits 5.5-7.5 $\mu \mathrm{m}$, but larger in $N$. amara and $N$. ulei. Parenchyma inconspicuous, vasicentric, aliform, and confluent. Crystals usually present in the rays.

Remarks

L. Williams (1936) described the general and the lens characters of three species of Ogcodeia (O. tamamuri Macbr. $=N$. glabra Spruce ex Pitt., $O$. tessmannii Mildbr. $=N$. glabra and O. ulei (Warb.) Macbr. $=N$. ulei $($ Warb. Ducke). He also recorded the numerous vessels, but his statement that parenchyma occurs both surrounding the pores and in fine, short tangential lines could not be confirmed as far as the lines are concerned. RECORD \& Hess (1940) based their description of Naucleopsis on one specimen of N. macrophylla Miq. The affinity of the wood with that of Ogcodeia and Noyera was pointed out. Their description of the genus Ogcodeia, based on one wood sample of each of 6 species, the names of which were not given, matches the description of $N$. macrophylla quite well indeed, and also agrees with the general description 
of Naucleopsis sensu Berg given by us. Noyera mollis (now Perebea mollis (Poepp.) Huber) is different from Naucleopsis in the less numerous and wider vessels. Loureiro \& Freitas (1968) described the lens characters of Perebea concinna $(=N$. concinna (Standl.) C. C. Berg). They mentioned a pore distribution of 7-17 per sq. $\mathrm{mm}$, considerably less than our value.

\section{OLMEDIA Ruiz \& Pavon}

plate II, fig. 3,4;plate IV, 3

BERG (1972) considered the genus as monotypic, Olmedia aspera R. \& P. being the sole species. Specimens formerly considered to belong in this genus were transferred by him to Pseudolmedia and Helicostylis. Three samples of $O$. aspera were available for investigation.

\section{General characters}

Wood uniformly cream-coloured; texture rather fine, parenchyma clearly visible on cross sections; slightly roey-grained. Moderately heavy, vol. weight 0.78 .

\section{Microscopical characters}

Vessels: Moderately few, 7.5-10 (4-13) per sq. $\mathrm{mm}$; for about $50 \%$ in radial multiples of $2-4$, seldom in clusters, fairly regularly distributed. Outline round, diameter generally $100(70-140) \mu \mathrm{m}$; perforations simple; intervascular pits angular with enclosed slit, 7-10 $\mu \mathrm{m}$. Vessel members on the average 530 (370700) $\mu \mathrm{m}$ long.

Fibres: Non-septate, exceptionally one or two septate fibres seen in macerations. Rather irregularly arranged. Diameter 16-22 $\mu \mathrm{m}$, walls thin, c. $2 \mu \mathrm{m}$; gelatinous walls present in nearly all fibres; pits very small, on radial walls only; length on the average $1050(640-1400) \mu \mathrm{m}$. Fibre/vessel member length ratio 2.- (1.7-2.2).

Rays: 1- and 2-4 (5) cells wide. The uniseriates scarce, consisting of square and upright cells, very low, 2-8 cells high. The multiseriates mostly 2-4 cells wide, the uniseriate wings often restricted to one or two rows of upright cells, but sometimes much longer; sheath cells nearly always present, though not completely enveloping the rays; on tangential section the cell sizes very irregular; rays sometimes vertically fused or diagonally dissected by a fibre; width $30-50 \mu \mathrm{m}$; up to 65 cells $(1700 \mu \mathrm{m})$ high. Pits to vessels scarce, rounded and half bordered or large and elongated. Latex tubes not observed. Brown cell contents absent, crystals very scarce. Average number 7 (5-8) per $\mathrm{mm}$.

Parenchyma: Apotracheal and paratracheal. Chiefly in regularly spaced, straight or slightly undulating, 5-8 (12) cells wide bands, which occasionally border the vessels or envelop them; paratracheal parenchyma usually present as an incomplete vasicentric ring. Strands of $2-4$ cells, on average $530 \mu \mathrm{m}$ long. No specific cell contents observed.

Diagnostic characters

Regularly spaced, moderately straight, broad bands of apotracheal parenchyma, non-septate fibres and the absence of latex tubes characterize the wood of Olmedia. 


\section{Discussion}

The wood of Olmedia aspera was first described by Williams (1936) based on specimens collected by himself in Peru. The same material was subsequently studied by RECORD \& HESs (1940) and by ourselves. Williams mentions trunks of $20-25 \mathrm{~cm}$ in diameter, but the material at hand (MADw s.n.) is $5 \mathrm{~cm}$ in diameter. Another specimen which we owe to the courtesy of Dr. R. L. Dressler is a piece of a stem of an arching shrub (Uw 21743). It shows the same features as the Williams' samples. Like Record \& Hess remarked, the wood by its "lamellated" structure resembles the wood of Ficus more than that of the other genera of the Olmedieae. This different wood structure combined with the absence of a very characteristic type of branch abscission present in all other genera of the Olmediaeae - anatomical details of which are described by KoEk-NoOrman \& Ter Welle (1976) - as well as differences in the floral structure lead BERG (1977) to exclude Olmedia from the tribe.

\section{PEREBEA Aublet}

plate III, fig. 4; plate IV, fig. 2, 4

BERG (1972) widened the concept of the genus to include several species assigned by previous taxonomists to other genera. Among them is the former genus Noyera Tréc. which became a section of Perebea. Of the eight species only the three most common ones with the widest distribution are represented by wood samples.

\section{General characters}

The wood is greyish or yellowish brown without a clear demarcation between sapwood and heartwood; straight-grained, texture moderately fine, moderately light, the vol. weight between $0.70-0.80$, much lighter $(0.53)$ in one sample of P. guianensis.

\section{Microscopical characters}

Vessels: Moderately few, on the average 7-8 (2-14) per sq. mm, slightly more numerous in $P$. guianensis (12-15 per sq. mm); mostly solitary, for about 20 $25 \%$ in radial multiples of $2-4$, fairly regularly distributed with a tendency towards a diagonal arrangement; outline oval or rounded, tang. diameter generally 100-160 (90-200) $\mu \mathrm{m}$, widest in P. guianensis; perforations simple; intervascular pits 7-9 $\mu \mathrm{m}$; thin tyloses occasionally present in $P$. guianensis and $P$. mollis; vessel member length on the average $460(370-560) \mu \mathrm{m}$, the total range from 240 to $680 \mu \mathrm{m}$.

Fibres: All septate, usually with 2-3 septae; arrangement irregular. Diameter mostly 18-20 (24) $\mu \mathrm{m}$, walls 3-4 $\mu \mathrm{m}$ thick; length on the average 1260 (10501460) $\mu \mathrm{m}$, range $500-1900 \mu \mathrm{m}$; pits very small, limited to the radial walls. Fibre/vessel member length ratio: $2.6(2-3.8)$.

Rays: Uniseriate and 2-5 cells wide. The uniseriates consisting of square and upright cells, rather frequent in $P$. guianensis and $P$. xanthochyma, but nearly absent in $P$. mollis; mostly $4-10$ cells high. The multiseriates mostly 2-3 cells $(20-40 \mu \mathrm{m})$ wide in $P$. guianensis, $4-6$ cells $(50-70 \mu \mathrm{m})$ in $P$. mollis and $P$. xanthochyma, generally with short uniseriate wings, often partly with longer 
wings; height usually $600-800 \mu \mathrm{m}$, but up to 1000 and $1250 \mu \mathrm{m}$ (50-68 cells). Pits to vessels scarce, round, half bordered, mostly in the square and upright cells. Latex tubes present. Often brown contents in the cells: crystals scarce, noticed in $P$. mollis and in P. xanthochyma. Average number 6.5 (5-8) per $\mathrm{mm}$. Parenchyma: Paratracheal in generally complete, narrow, aliform vasicentric rings, of ten confluent in tangential or diagonal direction over a short distance, the sheaths usually widest on the abaxial sides of the vessels, continuous bands rare, though fairly often present in $P$. mollis. Strands of 4 (2-8) cells. Pits to vessels large, irregular, mostly horizontal. Brown cell contents often present; crystals very scarce, noticed only in $P$. mollis p.p. and $P$. xanthochyma.

Diagnostic characters

As already stated before, it is very hard to find characters which are specific for Perebea, as Maquira and Perebea closely resemble each other in nearly all anatomical features, as they also do in morphological characters.

Remarks

RECORD \& Hess (1940) described the wood of Noyera mollis (at present $\boldsymbol{P}$. mollis ssp. mollis) and their description complies very well with our findings, as is to be expected since the specimens studied by them and by us are, at least partly, the same. Under the heading Perebea they treated wood samples of 5 species, only 3 of which, viz: $P$. castilloides Pitt. (now P. guianensis ssp. castilloides (Pittier) C. C. Berg), P. chimiqua Macbr. (now P. xanthochyma Karsten) and $P$. tessmannii Mildbr. are still considered as Perebea species at present. Of the other two $P$. concinna Standl. was transferred by Berg to Naucleopsis and $P$. laevigata Standl. from Panama could not be traced. They mentioned the rather aberrant structure of $P$. castilloides with non-septate fibres and the abundant parenchyma often occurring in wide concentric bands next to the more usual short aliform vasicentric rings. This, however, need not be considered as a really disturbing fact, since we found in our material banded parenchyma in a sample of $P$. mollis rather often. The absence of septate fibres in their material is more unusual as this character was always clearly present in our samples. In an earlier publication RECORD \& MELL (1924) described a sample of Perebea spec. (Yale 4952 = BW 5493) from Suriname. The herbarium voucher of this number has now been identified by Berg as $P$. mollis ssp. rubra. In their description they mentioned the high, and up to five cells wide rays and the occasional occurrence of bands of parenchyma apparently limiting growth rings, but otherwise present in wing-like patches about the pores, and the often septate fibres. A description which matches quite well our general description given above.

\section{PSEUDOLMEDIA Trécul}

plate II, fig. I, 2

In Berg's revision a number of species formerly considered to belong in Pseudolmedia were transferred to other genera like Helicostylis and Maquira, as will be discussed below. 
The material investigated consists of 18 samples belonging to 5 species (table 1). The genus comprises 9 species.

\section{General characters}

Colour yellowish brown, heartwood not different from the sapwood, except, according to ReCORD \& Hess $(1940,1944)$, in P. spuria with reddish brown heartwood not sharply demarcated from the thick grayish or pinkish brown sapwood. L. Williams (1936) described the heartwood of a large tree of $P$. multinervis (now P. laevis) as pinkish or dark brown. The wood is straight or slightly roey-grained; moderately heavy, vol weight $0.75-0.80$, or heavy, like in P. oxyphyllaria with a vol. weight of 1.0 .

Microscopical characters

Vessels: Number variable, on the average $10-15$ per sq. $\mathrm{mm}$, in samples of small-sized trees (Krukoff 6697, 7003) often more numerous: 30 or more per sq. $\mathrm{mm}$ and then resembling Naucleopsis; usually scattered but sometimes irregularly distributed, for about $30-50 \%$ in radial multiples of $2-3(4)$, multiples less frequent in P. laevigata; tang. diam. 100-150 $\mu \mathrm{m}$; intervascular pits 6-8 $\mu \mathrm{m}$; tyloses often present, generally thin, but occasionally very thick and sclerotic; often with solid white contents in $P$. laevigata, $P$. laevis and $P$. oxyphyllaria; vessel member length $350-500 \mu \mathrm{m}$.

Fibre tissue: Nearly all fibres septate, except in one sample of $P$. macrophylla; fibre arrangement irregular. Diameter 15-20 (24) $\mu \mathrm{m}$, walls 3-5 $\mu \mathrm{m}$ thick, in $P$. oxyphyllaria and $P$. spuria walls $6 \mu \mathrm{m}$ thick and the lumen narrow, c. $3 \mu \mathrm{m}$; sometimes a gelatinous layer present, pits small, simple, on the radial walls only; average length about $1100(800-1340) \mu \mathrm{m}$. Fibre/vessel member length ratio 2.60 , range $2.25-3.10$.

Rays: Uniseriates scarce, short, consisting of square and upright cells, sometimes also a few procumbent cells present. The multiseriates mostly 3-4 (2-6) cells wide with uniseriate margins, 1-3 cells high; width $30-50 \mu \mathrm{m}$ and up to $70 \mu \mathrm{m}$; height variable between 30 and 100 cells or 300 and $800(1400) \mu \mathrm{m}$ respectively, the large rays often dissected by one or two diagonal fibres (plate II, fig. 2). Pits to vessels large, mainly horizontal. Latex tubes present. Many cells with brown contents, rhombic crystals sometimes present, very numerous in $P$. oxyphyllaria and $P$. spuria. Number on the average 7-8 (5-11) per $\mathrm{mm}$.

Parenchyma: Paratracheal, vasicentric in complete and incomplete rings, often aliform with long wings in $P$. laevis and $P$. laevigata in part of the growth ring, but mostly confluent into irregular, wavy, narrow, 3-6 cells wide, bands; strands of (2)4-8 cells; crystals present in $P$. laevigata, $P$. oxyphyllaria and P. spuria.

Diagnostic characters

Paratracheal parenchyma predominantly arranged in wavy irregular bands: rather wide and often high rays, often obliquely crossed by fibres: frequent occurence of crystals in rays and parenchyma cells.

Discussion

Of $P$. macrophylla two wood samples were available, both collected by Krukoff, 
the herbarium vouchers of which were identified by Berg. The wood structure of one of them (Uw $16202=$ Krukoff 8524) differs in various characters from the general structure of the genus as described above: the fibres are hardly septate, the rays not over 3 cells wide and not dissected by fibres, the parenchyma is narrow vasicentric instead of aliform confluent.

The most extensive information on the genus to be found in the literature is RECORD \& Hess's (1940) description chiefly based on $P$. spuria and $P$. oxyphyllaria. In 3 other species, viz. $P$. multinervis, $P$. obliqua and $P$. scabra, they noted a different parenchyma distribution and a larger fibre width. In Berg's revision $P$. multinervis is placed in synonymy with $P$. laevis. Material of $P$. laevis seen by us, is rather uniform and agrees quite well with the general aspect of Pseudolmedia. However, like stated above, individual variations in structure happen to occur occasionally in each genus. P. obliqua was transferred by Berg to Maquira coriacea and P. scabra to Helicostylis scabra. This is in accordance with their anatomy as neither in Maquira nor in Helicostylis (except $H$. turbinata) parenchyma confluent over a long distance occurs.

\section{GENERAL DISCUSSION}

From the key and descriptions it becomes clear how much the genera Helicostylis, Maquira, Naucleopsis, Perebea and Pseudolmedia have in common in their wood structure. As already pointed out in the remarks following each generic description, many of the incongruities signalized by ReCORD \& Hess (1940) have been eliminated by BERG's (1972) new concepts of the generic circumscriptions. On the other hand some inconsistencies in the general aspect of most of the larger genera still remain. Sometimes it is one out of several samples of the same species that shows a slightly different wood pattern, like Pseudolmedia macrophylla $(\mathrm{Uw} 16202=$ Krukoff 8524$)$ resembling a Helicostylis or two samples of Perebea mollis (Uw 8080, Uw $19268=$ Krukoff 6985, Krukoff 1289) the parenchyma distribution of which is more like Pseudolmedia. Or in Naucleopsis, N. amara (Uw $19340=$ Krukoff 1406) being different from the other species in its number of vessels. However, these differences are much smaller and of a different nature than those between Olmedia and the other genera, Olmedia being distinguished by the apotracheal banded parenchyma, the bands being regularly spaced and more or less straight, a type of parenchyma distribution not occurring in any other genus of the Olmedieae, but resembling that in Ficus, Malaisia, Pseudomorus, Sorocea, Sparattosyce and Trophis. To the latter genus Olmedia seems to be related (Berg 1977). MetCalfe \& ChalK (1950) also list Trymatococcus among the genera with banded non-confluent parenchyma, but this could not be confirmed in our material of the three species of this genus. In Olmedia septate fibres are extremely rare, which is another character distinguishing it from the other genera. However, in Helicostylis septate fibres are not of a general occurrence and in some specimens like in $H$. turbinata they could not be traced at all. Moreover, in the Anatomy of the Dicotyledons Helicostylis is not cited among the genera with septate fibres, 
indicating that their presence is not as evident as it is in the other genera. Thus, the parenchyma distribution in particular is an argument in favour of BERG's (1976) recent exclusion of Olmedia from the tribe.

TIPPO (1938), in a special paragraph of his general survey of the anatomy of the family, drew attention to the distribution of septate fibres within the Moraceae. From a total of 28 species with septate fibres 25 belong to the subfamily Artocarpoideae; in all Olmedieae septate fibres are present. He also found them in two species of Olmedia, but as he did not give names or numbers of collections it is hard to be certain whether the specimens seen by him really belong to what is now considered as Olmedia - i.e. O. aspera R.\& P. only-, or not. Another genus that would fit in well with the Olmedieae is the African genus Antiaris, placed by BUREAU (1873) in the Olmedieae, which was followed by BENTHAM (1880) and more recently by CORNER (1962). From other paleotropical genera which Corner tentatively placed in the Olmedieae, Sparattosyce would not fit. Of two more genera cited in this context, viz. Antiaropsis and Mesogyne, no material was available. According to TipPo (1938) Mesogyne possesses septate fibres which fact he stresses as being exceptional in the Dorstenieae, the tribe in which Mesogyne was included at that time. As a matter of fact in none of the tribes, beside Olmedieae, septate fibres were found by him, with the exception, however, of Ficus religiosa in the Ficeae and Prainea in the Conocephaloideae. Thus the septate fibres of Mesogyne form a strong argument in favour of Corner's opinion that Mesogyne is closely related to Antiaris. (The wood of Prainea shows a certain resemblance to the Olmedieae not only in the septate fibres, but also in its aliform-vasicentric parenchyma distribution. CORNER (1962) placed Prainea in the alliance of Artocarpus and Malaisia, stressing, however, its own character.) Genera belonging to the tribe Brosimeae show a certain resemblance to the Olmedieae in their parenchyma distribution (LINDEMAN \& MENNEGA 1963) but they differ in other characters, a.o. by the complete or almost complete absence of septate fibres.

In general, the structure of the wood of the Olmedieae may be considered as advanced. Features like scalariform vessel perforations, strongly heterogeneous rays, diffuse apotracheal parenchyma (cf. the characters listed by TIPPO 1938), usually considered as primitive structures are not encountered in any of the genera. If septate fibres and a considerable amount of paratracheal parenchyma are an indication of specialization then Helicostylis has to be placed at the base of the series and Castilla at the top. The other genera are to be placed somewhere in between. 

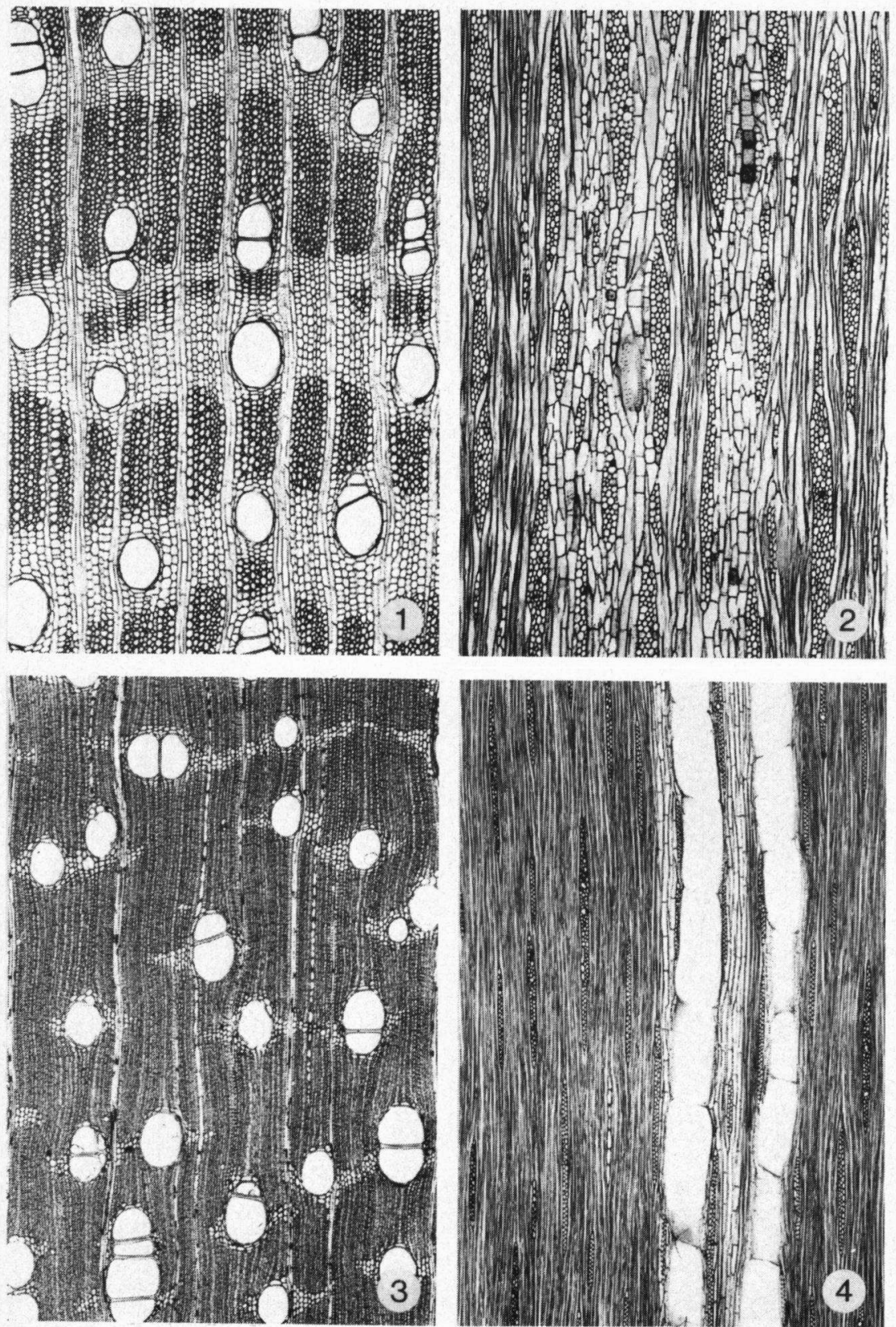

Plate I. Fig. 1, 2: Castilla ulei (Uw 8827), cross sect. $\times 36$, tg. sect. $\times 36$; fig. 3,4 : Helicostylis scabra (Uw 16222), cross sect. $\times 36$, tg. sect. $\times 36$. 
24
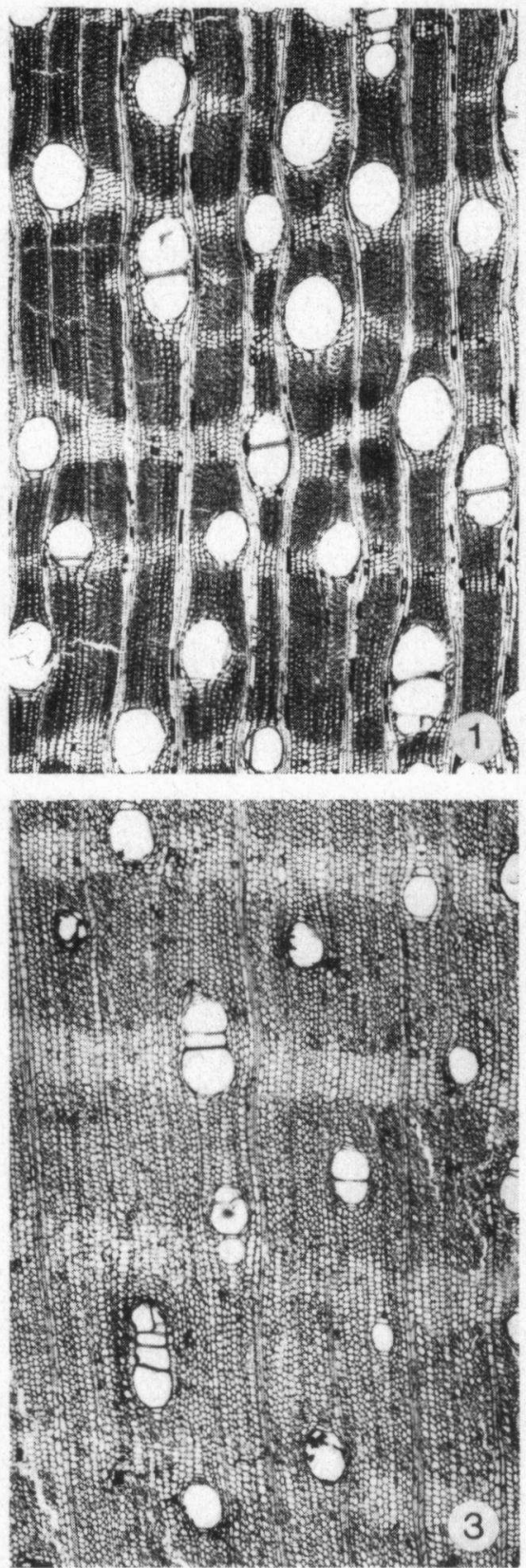

4. M. W. MENNEGA AND M. LANZING-VINKENBORG
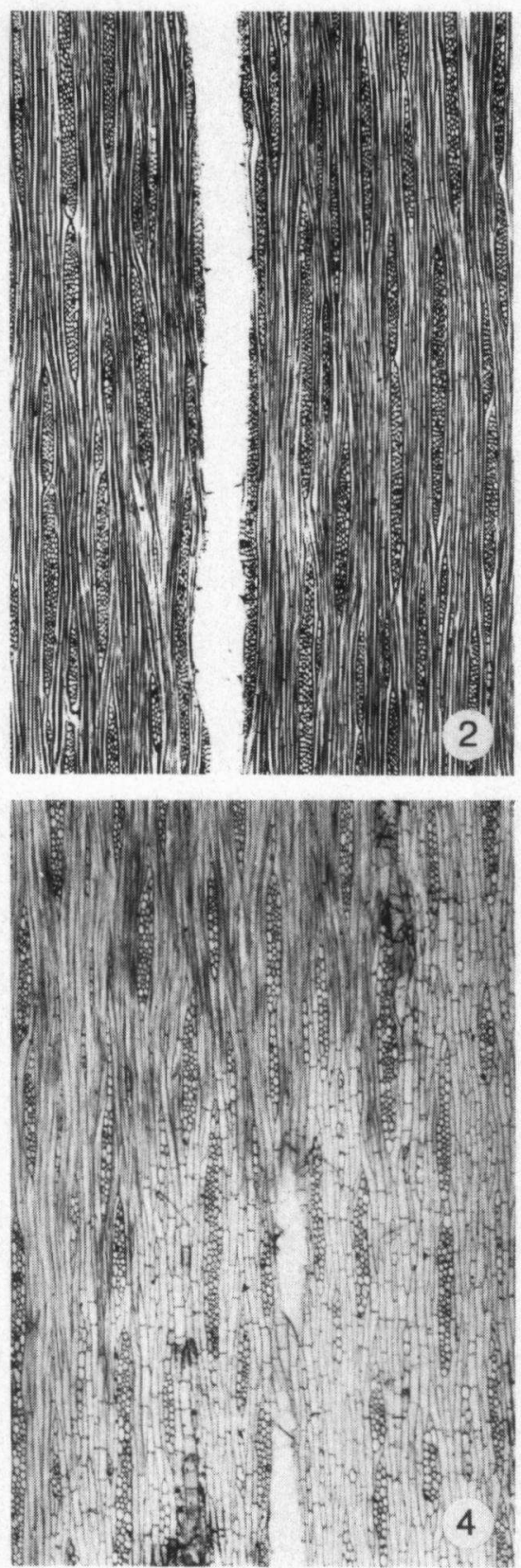

Plate II. Fig. 1, 2: Pseudolmedia laevis (Uw 11817), cross sect. $\times 36$, tg. sect. $\times 36$; fig. 3, 4 : Olmedia aspera (Uw 18429) cross sect. $\times 36$, tg. sect. $\times 36$. 

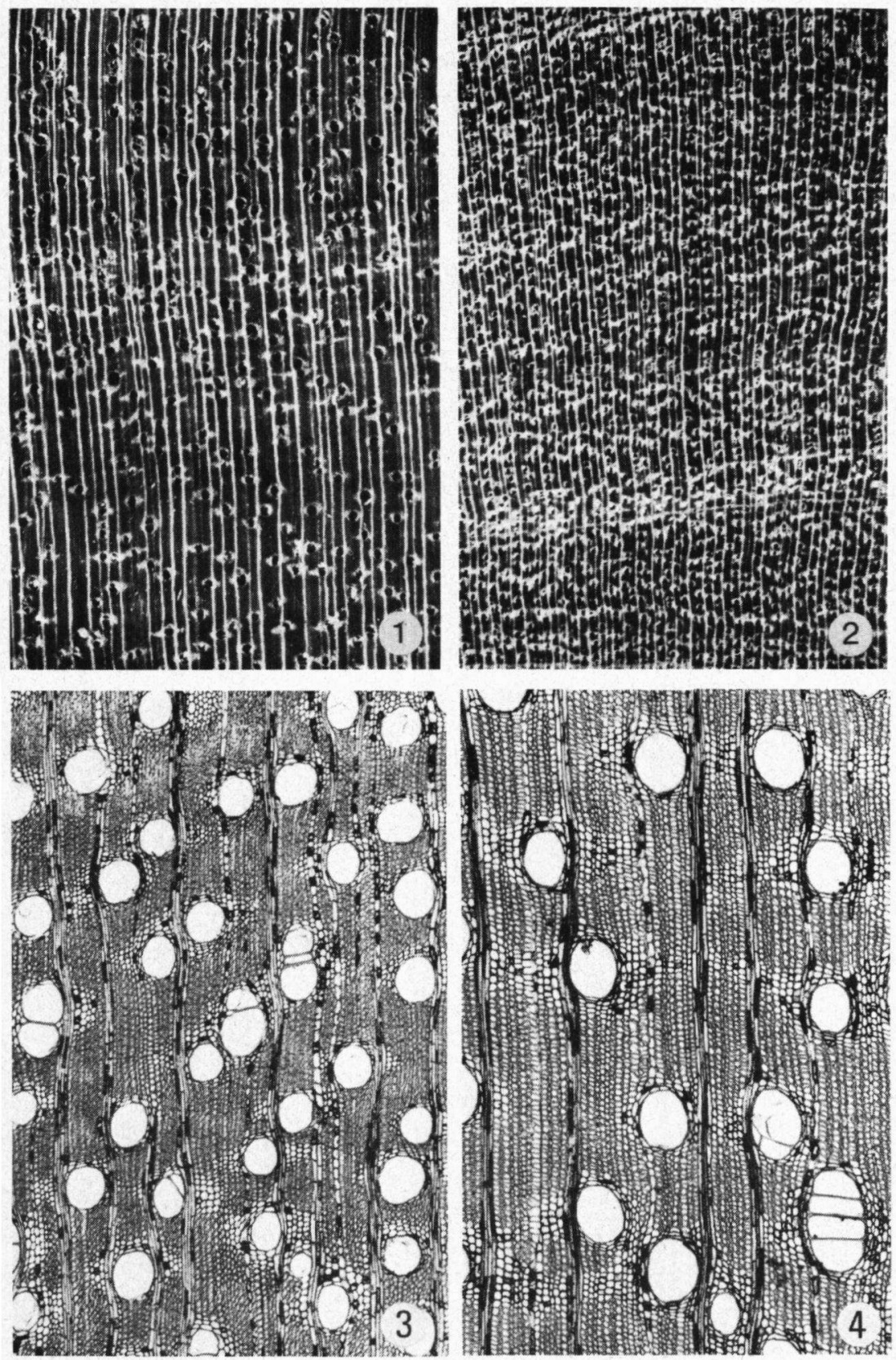

Plate III. Fig. 1: Heliocostylis tomentosa (Uw 6836), cross sect. $\times 10$; fig. 2 : Naucleopsis glabra (Uw 7549), cross sect. $\times 10$; fig. 3: Maquira coriacea (Uw 17149) cross sect. $\times 36$; fig. 4 : Perebea guianensis ssp. indet. (Uw 16183) cross sect. $\times 36$. 
26

$\int_{a}$

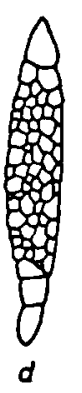

(1)

A. M. W. MENNEGA AND M. LANZING-VINKENBORG
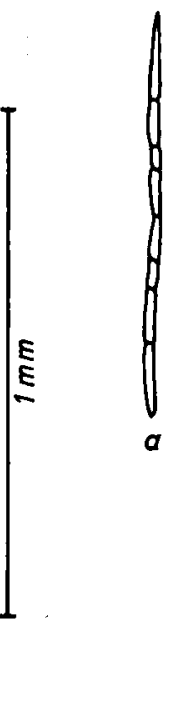

8
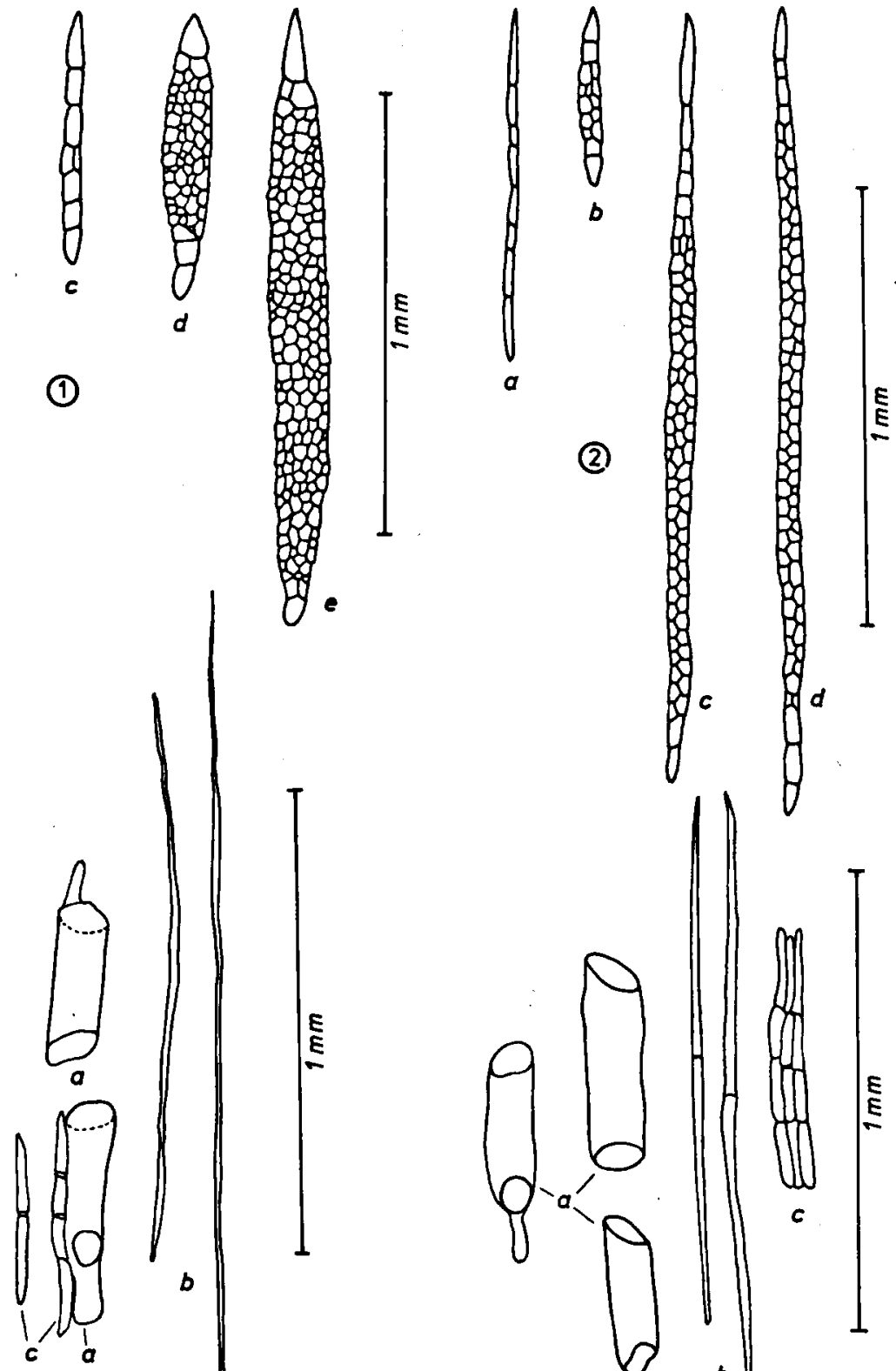

(3)

(4)

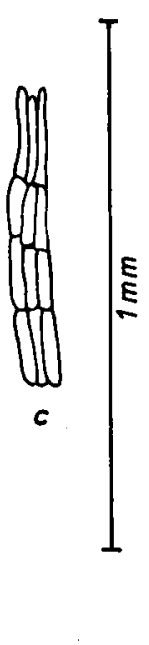

Plate IV, camera lucida drawings. Fig. 1: Maquira coriacea (Uw 7886), various ray types, type "e" being the most common one; fig. 2: Perebea guianensis ssp. guianensis (Uw 8241), types of rays among which types "c" and "d" are the most frequent; fig. 3 : Olmedia aspera (Uw 21743) elements from macerated wood; fig. 4 : Perebea xanthochyma (Uw 18431). 


\section{ACKNOWLEDGEMENTS}

Useful discussions with Dr. C. C. Berg as well as his suggestions and critical comments on the manuscript are gratefully acknowledged. Our thanks are also extended to curators of wood collections who kindly provided us with valuable wood samples, and to those who collected material in the field, among them Dr. R. L. Dressler, who upon our request immediately made a special effort to collect material of Olmedia aspera. We are much indebted to Mr. L. Y. TH. Westra for his careful correction of the English text, and to Messrs. A. Kuiper and T. Schipper for their assistance with photographs and drawings.

\section{REFERENCES}

Bentham, G. (1880): Urticaceae. In Bentham \& Hooker, Genera Plantarum 3 (1): 341-395. BERG, C. C. (1972): Olmedieae, Brosimeae (Moraceae). Flora Neotropica. Monograph no. 7. Hafner Publ. Comp. New York.

- (1977): The Castilleae, a tribe of the Moraceae, renamed and redefined due to the exclusion of the type genus Olmedia from the "Olmedieae". Acta Bot. Neerl. 26: 73-82.

Bureau, E. (1873): Artocarpaceae. In De Candolle, Prodromus Systematis Naturalis Regni Vegetabilis 17: 280-288.

CORNER, E. J. H. (1962): The classification of Moraceae. Gard. Bull. Singapore 19: 187-252.

Koek-Noorman, J. \& B. J. H. TER Welle (1976): The anatomy of branch abscission layers in Perebea mollis and Naucleopsis guianensis (Castilleae, Moraceae). Leiden Bot. Series 3 (in press).

Lindeman, J. C. \& A. M. W. Mennega (1963): Bomenboek voor Suriname. 's Lands Bosbeheer. Paramaribo.

Loureiro, A. \& M. Freitas da Silva (1968): Catalogo das Madeiras da Amazonia. Belem.

MetCalfe, C. R. \&L. Chalk (1950): Anatomy of the Dicotyledons. Clarendon Press. Oxford.

ReCORD, S. J. \& R. W. Hess (1940): American Woods of the family Moraceae. Trop. Woods, no. $61: 11-54$.

- \& - (1944): Timbers of the New World. Yale University Press. New Haven.

- \& C. D. Mell (1924): Timbers of Tropical America. Yale University Press. New Haven. TIPPO, O. (1938): Comparative anatomy of the Moraceae and their allies. Bot. Gaz. 100: 1-99. Williams, Ll. (1936): Woods of Northeastern Peru. Field Mus. Nat. Hist. Bot. Ser. 15: 71-95. 